\title{
論文・資料
}

\section{CFF で示される中心視と周辺視の感度差}

\author{
NHK 放送科学基礎研究所 福田忠彦
}

ちらつき光に対する視野各部の感度特性を $\mathrm{CFF}$ を指標に求めたところ, 小面積視標の場合は網 膜上の視細胞（錐体・杆体）の密度分布と強い相関を示すこと, 大面積視標の場合は網膜周辺部に おける面積効果により, 周辺部で $\mathrm{CFF}$ が最む高くなること, また, 眼球運動中の方が視線を固定 した場合より CFF が高いことなどが明らかになった。

\section{1. ま え がき}

画像技術の問題を取り扱う場合，画像の持っている物 理的な構造とそれに対面する人間の視知覚との対応関係 を充分に考慮しなければならない，特に画像を経済的に 効率よく伝送することを考えるためには，視覚の性質を うまく利用する必要がある.

ところで，ディスプレイが多様化する中で，画面を大 きくしようという動きがあるが，画面が大きくなると像 が網膜上に占める割合が大きくなり，視線方向の視覚 （中心視という）の性質のみならず，視線方向以外の視覚 （周辺視という）の性質む充分考慮しなければならなくな る. 特に周辺視機能は形や時間的に変化する視覚情報に 対して重要な働きをしているといわれて扣り，また，視 線運動以前の視覚情報はすべて視野周辺部から視覚系に 入ってくることをあわせ考えると，周辺視機能を明らか にすることは，工学的必要性加いってむ，また，視覚 系そのむのの理解のためにあ重要であるといえる.

そこで，本報告では，周辺視機能の重要な要素のひと つと考えられている明滅する光（フリッカー光）に対す るヒトの視覚系の感度特性（フリッカー特性）を取り上 げ，視野各部位に打けるその特性を明らかにした。

一般に，フリッカー光によって視覚系に生ずるちらつ き感覚は, 必ずしあフリッカー周波数とは一致しないゆ が，フリッカー周波数をしだいに高くするとちらつき感 は，やがて消失して定常光感覚となる，ちらつき感がち ょうご消失する境界の周波数を臨界フリッカー周波数 (Critical Flicker Frequency 略して CFF) ということ は，衆知のとおりであり，CFF によって視野各部位と フリッカー特性の関係を明らかにしようとする研究は,

"The Sensitivity Differences Measured by CFF between Central and Peripheral Retina" by Tadahiko Fukuda (NHK Broadcasting Science Research Laboratories. Tr kyo)
歴史的に古くから行われている2)。しかし，乙れまでの 研究はいずれも視覚現象の一側面のみを捉えたものが 多く，全体を統一的に扱ったものはなかった，そてで， 本論文ではフリッカー刺激光の物理条件を拡大し，統一 的な測定を行い，視野全体のフリッカー特性を明確にし た.さらに，乙の種の測定では初めて眼球運動の効果を 積極的に取り入れたところ，いずれむこれまでには見ら れなかった刺激の物理構造と視覚現象の対応が明らかに なった。これらのデータは視知覚の基本特性の明確化に 寄与するだけでなく，工学的には例えば新しいテレビジ ヨン方式決定や人間工学上の有効な基礎資料之なるであ ろう。

\section{2. 実験装置と実験方法}

本実験では，半円形回転セクターによって正弦波状に 輝度を変調することが可能なフリッカー発生器を用い, これとフリッカー視標（以下単に視標之呼ぶ）呈示部を ライトガイドで結ぶことにより，視標呈示位置の調整を 容易にしている，視標呈示部は簡単な積分球でできてお り，その開口面が視標となる。乙の方法によれば，一様 輝度を有する比較的大きな視標が得られる。実験に用い た視標はすべて円形であり, 積分球開口面に光学マスク を設けることによって所定の大きさを選択する，一方， 視標輝度はフリッカー発生器内に設けられた NDフィ ルターにより調節する。なお，フリッカー発生器の光源 には八ロゲンランプを用いているので，呈示されるフリ ッカー光はほぼ白色に近い.てのような視標を図 1 に示 すように視野各部の測定部位に固視点ととむに同一視距 離（約 $1 \mathrm{~m}$ ）飞呈示する。

被験者は顔面固定器を用いて頭部とあでを軽く固定 し，前方の固視点を単眼（右眼）で注視しながら，その まま視線を止めた状態で同時に周辺視野に呈示される視 


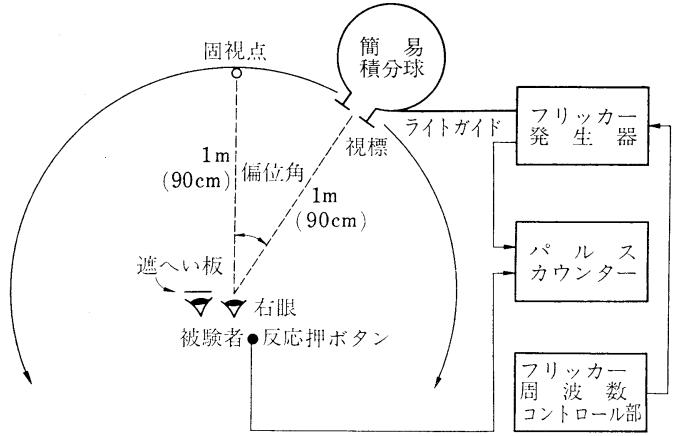

図 1 実験方法（暗視野での実験では固視点に赤色発光ダ イオードを用いる，明視野での実験では半径 $90 \mathrm{~cm}$ の半球型スクリーンを設け, 固視点はその上に赤い マークを設ける。また，視距離は暗視野では $1 \mathrm{~m}$, 明視野では $90 \mathrm{~cm}$ である)

Schematic diagram of the experiment. (As a fixation, a red LED is used in case of dark background and a red mark is mounted on the hemispherical screen in case of light background. The viewing distance to both a fixation point and a test field is $1 \mathrm{~m}$ in the former, and $90 \mathrm{~cm}$ in the latter)

標を網膜周辺部で観察する.

CFF の測定は極限法に準じた方法にしたがい, 初め に充分低い周波数のフリッカーを呈示し，次第に周波数 を高くして融合して見えるようになる瞬間の周波数を測 定する. 次に，融合周波数より充分高い周波数のフリッ カー光を呈示し，徐々に周波数を低くして，ちらつきが 知覚され始める瞬間の周波数を求める. 測定は 1 測定点 につき 8 回行うむのとする，なお，被験者の応答はパル スカウンターと連動した押ボタンによる.

本実験汇用いた被験者は成人男女 6 名で，1名を除き 22〜24 歳である. このうち 3 名はすべての実験に参加 したが，他の 3 名はその一部のみに加わった。いずれむ 視力 1.2 以上であり正常視機能を有する.

\section{3. 実騟-1（暗順応状態におけるフリッカー 特性)}

実験-1 では背景光がまったくなく, 視野全体が暗順 応状態にある場合の視野各部のフリッカー特性を, 視標 の大きさと輝度をパラメーターにとり, 視角偏位（視標 と視線のずれ角）の関数として求める.

\section{1 実験条件}

実験-1 で用いた視標は 100\% 輝度変調されたもので あり，その大きさは視角 $1 / 8^{\circ}$ 加 $8^{\circ}$ 亿至る 7 段階，平 均輝度を 0.3 から $6.0 \mathrm{~cd} / \mathrm{m}^{2}$ までの範囲とした。輝度の 上限はフレアを感じない值であり，下限は周辺視野にお ける見やすさを考慮し, 同時に, この輝度範囲内では視 標呈示位置による瞳孔径の変化が少ないことをあらかじ

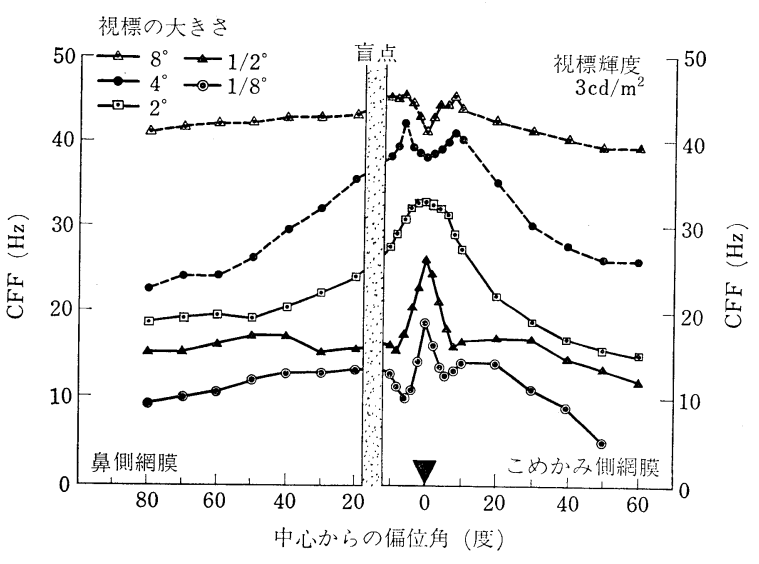

図 2 網膜部位々 $\mathrm{CFF}$ の関係におよぼす視標の大きさの 効果 (点線は被験者 2 名の平均値, その他は 6 名の 平均值を示している. 背景は暗黑, 視標の平均輝度 は $3 \mathrm{~cd} / \mathrm{m}^{2}$ である)

Mean critical flicker frequencies obtained along the horizontal plane.

The data for $2^{\circ}, 1 / 2^{\circ}$ and $1 / 3^{\circ}$ fields (solid lines) were obtained from six subjects and those for $8^{\circ}$ and $4^{\circ}$ (dashed lines) were obtained from two among them. The average luminance of the target is $3 \mathrm{~cd} / \mathrm{m}^{2}$ and the background is dark.

め確認して定めた値である。また, 固視点は約 $0.1 \mathrm{~cd} / \mathrm{m}^{2}$ に点灯した赤色発光ダイオードを用いた.

測定に先立ち，被験者は実験室（暗室）入室後 30 分 は暗順応する，測定は視標の大きさと輝度を固定し，視 角偏位を変数として水平方向部位之垂直方向部位につい て行ったが，詳細な測定は水平方向部位に限定した。い ずれの場合にあ変数である視角偏位が中心部位から周辺 部位の方向へ変化する場合之，その逆方向について行 い，測定方向による影響が少なくなるよう配慮した。

\section{2 実験結果}

以上のような実験条件下で得られた暗順応状態におけ る視野各部の CFF の変化を図2, 図3亿示す，いずれ む被験者 6 名の平均值である. 図 2 は水平方向部位につ いて視標の輝度を $3.0 \mathrm{~cd} / \mathrm{m}^{2}$ に保ち，視標の大きさをパ ラメーターとしたときの網膜部位による CFF の変化を 示している. 図のように, 視角偏位の関数として求めた CFF の変化は視標の大きさによって異なった傾向を示 す. 視標が $4^{\circ}$ および $8^{\circ}$ の場合には, 中心より約 $2^{\circ} \sim 10^{\circ}$ 周辺に偏った部位において，CFF が中心部位より高く なるいわゆる paracentral rise が認められる. 図は平均 值で示されているので相殺して認められないが， $2^{\circ}$ 視標 の場合にも，個々のデータをみると，2３の被験者は paracentral rise を示しているととが認められる.さら に視標の大きさが $8^{\circ}$ の場合については paracentral rise 


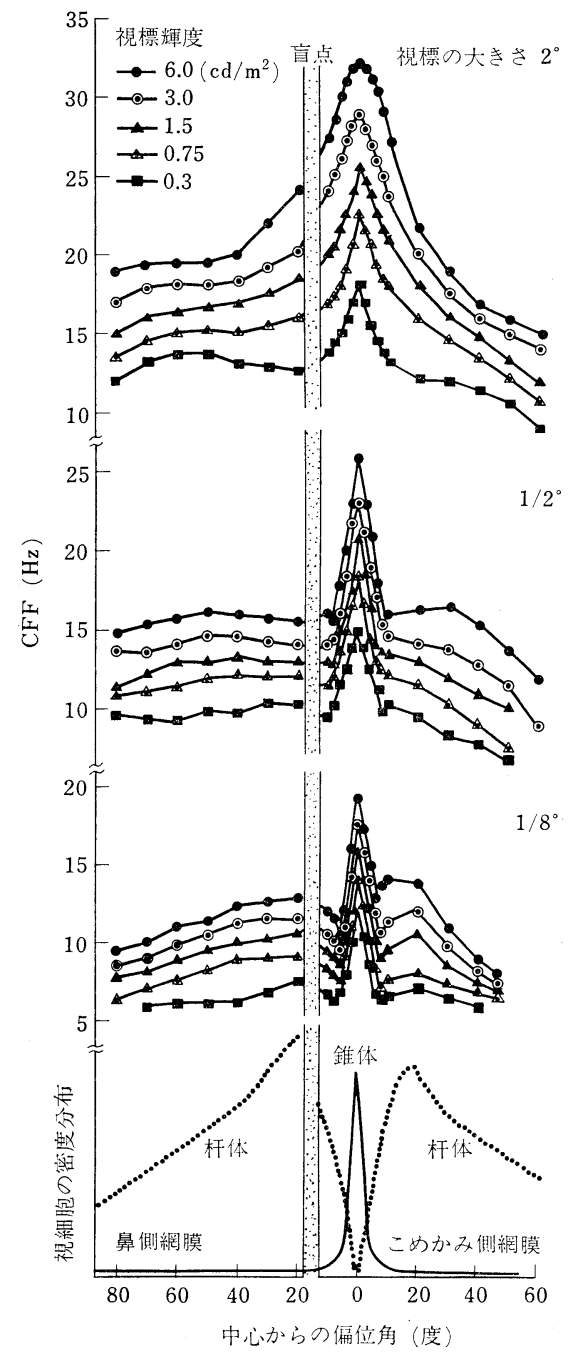

図 3 視標輝度が網膜部位と CFF の関係におよぼす効果お よび視細胞の密度分布3（背景は暗黒である）

Mean critical flicker frequencies for small test targets with dark background and the density distribution of cones and rods.

に加えててめかみ側網膜部位 $30^{\circ}$, 鼻側網膜部 $70^{\circ}$ 亿至 る範囲内の周辺部位全体にわたって中心部位より高い $\mathrm{CFF}$ を示している.

一方，規標の大きさが $2^{\circ}$ 以下の場合は，中心部位に おける $\mathrm{CFF}$ が最も高くなり，周辺部位では低い值を示 している. しかし，その部位による変化の様子は視標の 大きさによってそれぞれ特徴的である。すすなお，20の 場合は中心部位から周辺部位にかけて CFF は単調にゆ るやかに減少し，鼻側では $45^{\circ}$ より周辺の部位では一定 值之なる傾向を示すが， $1 / 2^{\circ}$ の場合には，中心部位付近 での CFF の変化が急峻になり, $10^{\circ}$ 以上の周辺部では ほぼ一定值となる，さらに視標の大きさが小さくなる
と, 中心部位付近での CFF の変化がいっそう急峻にな るとと屯に, 周辺部位 $6^{\circ}$ 付近で極小值を示し, 周辺部 位 $20^{\circ}$ 付近に第 2 の感度ピークを示すような傾向とな る.

同様の実験を垂直方向部位について行ったところ，定 性的にはほぼ水平方向と共通した結果が得られた。した がって, 図 2 の結果は水平方向部位固有の傾向ではな く, 視角偏位を変数とする場合, 大略各方向江共通して 得られる傾向であるとみてさしつかえない．

ところで, 視標の大きさが大きい場合に得られた結果 は局所的な意味での測定部位固有の值というょり, むし ろ部位間の相互作用等が影響しあっている值であるとみ るべきであろう。したがって暗順応状態に招ける刺激部 位と CFF の関係を検討する場合, 小面積の視標を対象 とする方に，特に視覚のなりたちを明らかにしようとす る立場からは重要な意義があるように思われる。乙のよ うな観点から，次に，われわれは小面積の視標に関する より詳細な測定を行った。

図 2 の結果は視標の輝度を固定し，その大きさをパラ メーターとして得られたものであるが, 同様の傾向が視 標輝度を変えた場合にも得られるか否をか検討するため に，視標輝度をパラメーターとして視野各部におけるフ リッカー特性を測定した，結果を図 3 に示す，図のよう に，いずれの場合にむ視標の輝度変化に伴い CFF の絶 対值は変化するが，中心部位における CFF と各周辺部 位における CFF の相対関係，すなうち視角偏位の関数 として表わした曲線の形状には変化は少ないといえる. これらの結果で特に注目されるのは, 視標が最も小さい $1 / 8^{\circ}$ の場合である. 図に示された曲線群はいずれむ前述 のように, CFF の変化が急峻な中心部位近傍の曲線と, 周辺部位 $20^{\circ}$ 近傍に第 2 の感度ピークを示す比較的ゆる やかな変化を示す曲線の 2 種類から成り, それらは中心 から 6〜 $8^{\circ}$ 偏った部位で交わっている，乙のような曲線 の形状は図 3 に示す網膜上の視細胞密度分布と対照して みると，きわめて強い相関性を示すととが認められる. すなわち, 中心部の急峻な変化な錐体に，そして周辺部 のゆるやかな曲線は杆体に対応する.

以上の結果から, 暗順応時の網膜中心部と周辺部との ちらつき感覚の差は, 視標の輝度よりむしろ面積が支配 的な影響を与え，視標の輝度は各部位における CFF の 絶対值に対して支配的な影響を与える。 また, 網膜部位 によるフリッカー特性の違いは本来視細胞の密度分布に 強く依存するすのと推定される，乙のことは，視標の大 きさが小さく，したがって部位間の相互作用が小さいと 思われる範囲内では，CFF 決定に際し錐体と杆体はそ

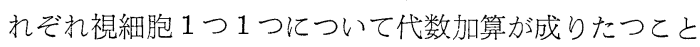


を意味する.しかし，視標の大きさが大きくなると部位 間の相互作用, すなわち, 視細胞以降の視神経部位にお ける非線形加算効果あるいは眼光学系等における非線形 要素によりその形状が変化すると考えられる.

\section{4. 実験-2（明順応状態におけるフリッカー 特性)}

実験-2 では，視野全体に一様な背景光を与えた場合 のいわゆる明順応状態にお打る視野各部のフリッカー特 性を, 背景光輝度レベルと視標の大きさをパラメーター とし, 実験-1 と同様, 水平方向の視角偏位の関数とし て CFF を求める.

\section{1 実験条件}

本実験では, 視野全体を一様に明順応状態となるよう な背景光を与える，乙のために内面がつや消し白色に塗 られた半径 $90 \mathrm{~cm}$ の半球形スクリーンを設け, 周囲から 最大 8 個の写真用タングステンランプで内部を照射する 方法をとった，スクリーン上での輝度の一様性は高輝度 の場合 $\pm 5 \%$ ，低輝度の場合 $\pm 10 \%$ 以内に保たれる。

視標はスクリーン上に設けられた円形アパーチャーを 通して呈示され，その大きさはアパーチャ一上に光学マ スクを設けるととにより $2^{\circ}$ から $1 / 16^{\circ}$ まで 6 段階選択 できるようにした，また，大面積視標の効果をあわせて 検討するための視標はこれとは別に作成し, 視距離 60 $\mathrm{cm}$ から観察した.

一方, 視標の平均輝度は背景光のそ机と等しくなるよ うにし，それぞれ $3,30,300 \mathrm{~cd} / \mathrm{m}^{2}$ の 3 段階とした。 視 標輝度の変調度はほぼ100\% であるが，視標が大きい場 合 $\left(16^{\circ}\right)$ のみ $33 \%$ とした。

なお，固視点はスクリーン上に大きさ約 $1 / 4^{\circ}$ の赤い円 形マークを貼りつけ, これを適宜移動させることとした。

被験者は 3 名で，実験に先立ち数分間明順応する，測 定要領は実験-1 とまったく同様である.

\section{2 実験結果}

以上のような実験条件下で小面積の視標について得ら れた明順応状態における視野各部の CFF の変化を図 4 に示す．いずれも被験者 3 名の平均値である.

これらの結果から次のような定性的な傾向を読みとる ことができよう。すなわち，視標の大きさおよび輝度が 実験範囲内に括いては，いずれの順応レベルにおいてす 中心部位に打ける $\mathrm{CFF}$ が最む高く, 周辺部位になるに したがって減少する，乙の減少の仕方は視標の大きさに より異なる. 順応レベル (視標輝度) が低い場合 $\left(3 \mathrm{~cd} / \mathrm{m}^{2}\right)$ には CFF が視標の大きさによって変化する様子は, 全 般的には実験-1 の暗順応状態で得られた傾向にきわめ て近い。しかし視標が小さい場合にはこの限りではな

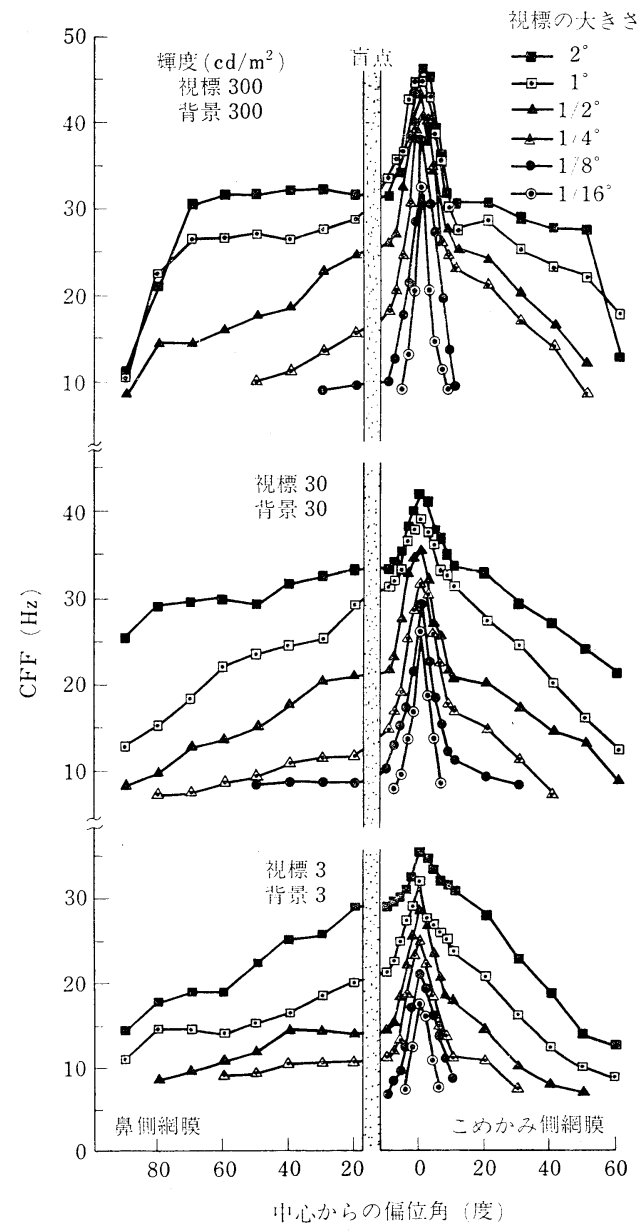

図 4 視標の大きさが網膜部位と CFF の関係におよぼす効 果 (背景は視標の平均輝度に等しくしてある)

Mean critical flicker frequencies for small test targets with light background.

The average luminance of test target was matched the luminance of the background $\left(30 \mathrm{~cd} / \mathrm{m}^{2}\right)$.

く,フリッカーが感じられる範囲は中心部位近傍の部位 に限られる。 したがって，暗順応時において見られたよ うな周辺部位での第 2 の感度ピークはみられない.また。 順応レベルが高くなるにしたがい, 中心部付近での CFF の変化がより急峻になる傾向が認められる.この傾向は すべての大きさの視標についていえる，さらに，いずれ の順応レベルに扔いてす周辺視野では小さい視標は背景 に融合してしまい，ちらつき感は失わ机る。

以上の結果を前述の暗順応状態で得られた結果と比較 すると興味深い. 暗順応状態では視角偏位の関数として 表わした CFF の変化は本来視細胞の密度分布に強く依 存するすのであるととを推定したが, 明順応状態で得ら れたてれらの結果は基本的にはこの推定が妥当であるて とを示している，つまり，明所視におけるこれらの結果 


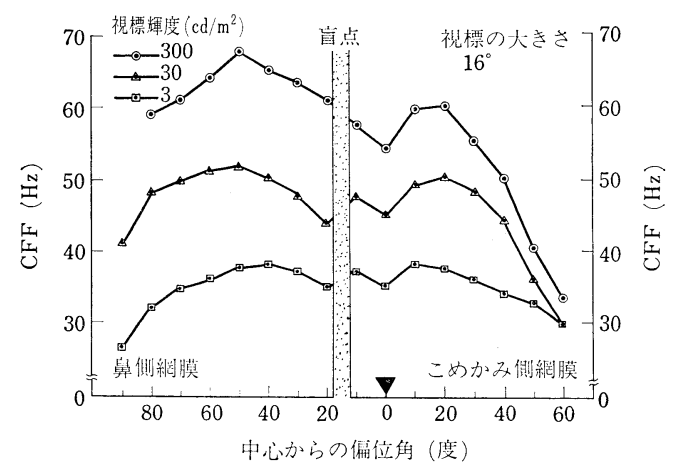

図 5 大面積の視標を用いた場合の視野各部における $\mathrm{CFF}$ の変化 (背景光はそれぞれ視標の平均輝度の $2 / 3$ の 輝度を有する)

Mean critical fricker frequencies for a large test target of $16^{\circ}$ with light background.

The average luminance of it was 50\% higher than that of its background.

には暗所視でその機能を発揮する杆体の機能は抑制され てその密度分布に対応すると思われる CFF 曲線の変化 は見られなくなり，明所視機能を有する錐体の密度分布 のみに刘応するような傾向を示しているてとがわかる.

ところで，視角の大きさの変化が CFF に与える効果 は，いずれの順応レベルに执いてあ中心部位より周辺部 位の方が大であるが，この傾向は視標が大きくなるに伴 いいっそう強調されることが予想される，そこで，次に $16^{\circ}$ の大視標を用いて視標の面積効果を確認するための 実験を各順応レベルについて行った。結果を図 5 に示 す.

この実験で用いた視標の変調度は $33 \%$ であり, 前述 の $100 \%$ 変調の視標を用いた実験の結果と直接比較する ことには問題があるが，図５の結果は大きな視標を用い た場合の視野各部の CFF の変化をよく表わしているよ うに思われる. 図のように，いずれの順応レベルに执い ても中心部位より周辺部位の方が $\mathrm{CFF}$ は高く, 鼻側部 位では中心から $40^{\circ} \sim 50^{\circ}$ 周辺に偏った部位で，また， こめかみ㑡では $10^{\circ} \sim 20^{\circ}$ 周辺に偏った部位に执いて最 大となる。乙のような傾向は順応レベルが高いほど著し く,また鼻側部位の方がこめかみ側部位より一般に CFF は高い

このように，視標が大きくなると周辺部位の方が $\mathrm{CFF}$ が高くなるが，これは小さな面積の視標を用いて得られ た図 5 の結果から予想されたと㧍り，周辺部位における 面積効果，すなわち空間加重効果が中心部位のそれより 大であるととによるあのと思われる，むち万んとの場合 の空間加重効果は視細胞以降の視神経部位で生ずる.

\section{5. 実験-3（眼球運動がフリッカー知覚にお よぼす効果：CFF の動特性)}

一般に，従来の古典的なフリッカー視野測定において は，固視点を定め，てれを注視するてとによって視線を 固定し，所定の部位に視標が投影されるような方法がと られている，われわれも，実験-1，実験-2 亿おいては 同様の方法をとった．しかしながら，通常われわ机は視 線を動かしながら視覚系に入ってくるさまざまな刺激に 対して反応しているわけであるから，眼球運動中の特性 を明らかにするととに，機能的にも実用的にも重要な意 義があると考えられる。

実験-3では，このような観点から,眼球運動中の CFF を視野各部に㧈いて測定し，フリッカー知覚に対する眼 球運動の効果を検討する。

\section{1 実験条件}

実験方法は基本的には前述の実験と同様であるが，本 実験では固視点の代りに運動視標を注視点とする，運動 視標はガルバノメータースポットを半球形スクリーン上 に投影し，乙れを電気信号で正弦波状に駆動する.

本実験では視標平均輝度および背景光輝度を実験-2 と同様, 等しく $30 \mathrm{~cd} / \mathrm{m}^{2}$ 亿固定し, 被測定網膜部位を 中心部位扔よび水平方向鼻側 $40^{\circ}$ の部位に限定した。 こ の場合, 視標が投影される網膜部位は眼球運動とともに 変化するので，乙こでは刺激される部位の中心を刺激部 位と呼ぶことにする。

運動視標は中心部位での測定においては円形視標の下 端を中心に，また周辺部位での測定においては視標から 水平方向に $40^{\circ}$ 周辺に偏った位置を中心に，それぞれ正 弦波状に水平方向に往復運動するように呈示し，その振 幅を $8^{\circ}$ 抢よび $1^{\circ}$, 周波数を $0.2,0.5,1.0 \mathrm{~Hz}$ の 3 段階 とした，なお，乙の運動視標の大きさは約 $0.2^{\circ}$ である。 一方, 視標の大きさは $1 / 4^{\circ}, 1 / 2^{\circ}, 1^{\circ}, 2^{\circ} の 4$ 段階とした. 本実験で用いた被験者は，実験-2 と同じ 3 名である。

\section{2 実験結果}

以上のような実験条件下で求めた測定結果を図 6 亿示 す．測定値はいずれす 3 名の被験者の平均值である，図 6 は視標の大きさを変数としたときの眼球運動時の CFF の変化を，実験-2 で得られた視線を固定した場合 のデータととむに，それぞれ中心部，および鼻側 $40^{\circ} の$ 部位について示している. 同時に, 運動視標の周波数の 効果，振幅の効果をむ表わしている.

図 6 亿示すように，眼球運動はフリッカー感度を高め る要素として働くことは明白である。しかし，その様子 は中心部位之周辺部位とでは多少異なっているように思 われる。すすなわ方, 視標の大きさが小さい場合には眼球 


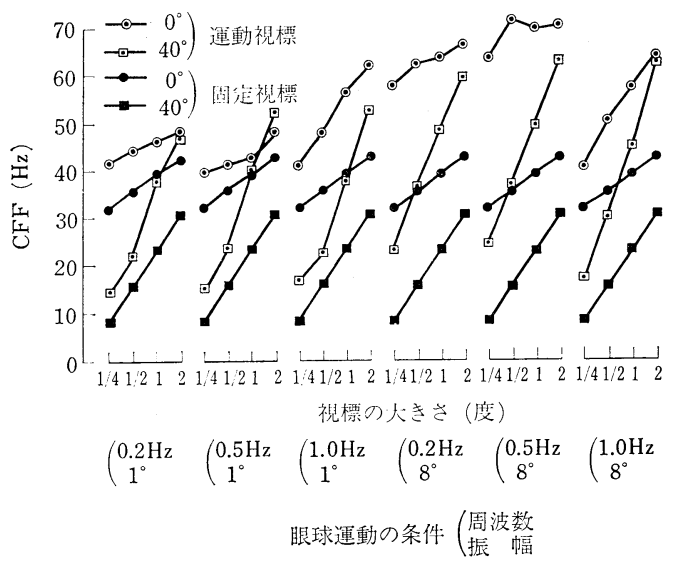

図 6 眼球運動がフリッカー知覚におよぼす効果(視標およ び背景の輝度は $30 \mathrm{~cd} / \mathrm{m}^{2}$ である)

The effect of eye movement on flicker perception. The average luminance of a target was matched the luminance of the background $\left(30 \mathrm{~cd} / \mathrm{m}^{2}\right)$.

運動の効果は周辺部位より中心部位の方がより大である が，視標が大きくなると周辺部位の方がより大きな効果 を示すようになる。たとえば，振幅 $1^{\circ}$, 周波数 $0.5 \mathrm{~Hz}$ の場合には，視標の大きさが $2^{\circ}$ のとき，周辺部位の方 が中心部位より CFF が高くなっている，てのような傾 向は視標が大きくなれば，乙の他の眼球運動条件下でむ 見られることは想像に難くない，事実，16の視標を用 いて行った結果は，乙の推定を裏づけるあのであった。

一方, 眼球運動の振幅の効果は中心部位では $0.2,0.5$ $\mathrm{Hz}$ の場合に認められるが $1 \mathrm{~Hz}$ においては認められな い. 周辺部位に执いては，いずれの周波数に関してむ同 じ程度の効果が認められる。総じていうならば，振幅 $1^{\circ}$ より 80 の方が眼球運動の効果は大きいといえる.

また，眼球運動の周波数の効果は中心部位では認めら れる、ただし振幅によって傾向の違いはある。しかし， 周辺部位においてはその効果は少ない．

いずれにしてす，眼球運動が CFF に与える効果は視 標が大きいほど大きく, 視標が大きい場合には周辺部位 の方が大きい, また, 眼球運動に関しては, 視標の大き さに応じて, 最む $\mathrm{CFF}$ が高くなる最適な運動条件, た とえば，最適眼球回転角速度といったものが存在するす のと思わ机るが，乙れがごのような值になるかは本実䀦 結果のみからは明白にできない。

\section{6. まとめと考察}

以上の実験から次のような結果を得た。

（1）視角偏位と CFF の関係は，基本的には網膜上 の視細胞の密度分布に強く依存するむのであるが，ての 関係は主として視標の大きさと順応レベルによって変化
する.

（2） CFF に対する面積加算効果は視野周辺部の方 が中心部位より大である. その結果, 視標が小さい(約 $2^{\circ}$ 以下）場合には中心部位に㧍ける $\mathrm{CFF}$ が最む高いが， 視標が大きい場合には逆倍周辺部の方が高くなる.

（3）鼻側網膜部位の方が，乙めかみ側より CFF は 高い.

（4）眼球運動時にはフリッカーに対する感度が上昇 する. この場合, 視標の大きさによって CFF が最大と なる眼球運動の条件は異なる。一般に，視標が比較的大 きい場合にはこの傾向は周辺視野において著しい.

以上の結果は単眼による測定結果であり, 実際には両 眼での特性が問題になるわけであるが，Ireland ${ }^{4)}$ の報 告によれば単眼の CFF 之雨眼の CFF はほぼ等しいと 考えられるので, 単眼で得られたてれらの結果を, その まま両眼の特性と理解してむ問題はないむのと思われ る. 乙の場合, 左右視野汇関しては結果 (3) 加鼻側網 膜部位における特性が視野周辺部の特性を表わすむのと 考えられる.

このように, 視角偏位と CFF の関係を求める場合, その目的が視環境に対する眼の特性を求めるととにある 場合は，視標が物理的に一定であればよいが，それが網 膜以降の視覚機構その屯のの理解にある場合には, 視標 は網膜上で一定でなければならない，ての点に関して特 に問題となるのは視標輝度であろう。視標輝度を網膜上 に打いて一定にするには瞳孔径を一定に保たなければな らない，そのために一般には人工瞳孔を用いるが，これ は視野を制限するので本実験には適当でない，そこでわ れわ机は暗順応状態の測定においては視標輝度を視標呈 示位置による瞳孔径変化が少ない範囲内に止め, また明 順応状態の測定においては背景光輝度と視標の平均輝度 を等しくなるようにすることによって，乙の問題を一応 解決している.したがって, 得られた結果と視覚系の構 造との対応を考えることも近似的には可能であると考え られる。

\section{7.むす び}

以上, 視野各部のフリッカー特性を心理物理的手法に よって測定した結果について述べた。ここでは視野各部 固有の性質を取り上げたが，視野各部位間の相互関係を 積極的に取り上げることによって，より一般的なフリッ カーに対する視野の性質が明らかになる。 また，工学的 にはフリッカー光の波形による違いも重要な課題と思わ れる。

こてで得られた結果は，いずれす巨視的な視覚系の性 質とその法則性の記述が中心であり，それらの基礎とな 
る視覚系の微細なメカニズムを明らかにするには至って いない，そのためには当然，充分な生理データの裏づけ が必要であろう.

おわりに，ての研究の機会を与えていただき，また激 励をいただいた NHK 放送科学基礎研究所 樋渡所長は じめ, 日頃ご指導いただいている渡部主任研究員, 視聴 科学研究室 坂田室長, 実験隹力された評定者, 実習 生諸氏に深謝する。

(昭和 52 年 8 月 11 日受付)

\section{〔参考文献〕}

1) T. Fukuda: Subjective Frequency in Flicker Per- ception, Perceptual and Motor Skills, 45, Aug. (1977) 203-210

2) たとえば W. W. Abney: The Sensitiveness of the Retina to Light and Colour, Phi]. Trans. Roy. Scc. (London) 190A (1897) 155-195

3) G.A. Österberg: The Topography of the Layer of Rods and Cones in the Human Retina, Acta. Ophthalmol., Suppl. VI (1935)

4) F.H. Ireland: A Comparison of Critical Flicker Frequencies under conditions of monocular and binocular stimulation, J. exp. Psychol., 40 (1950) 282-286

\section{テレビジョン学会誌投稿規定 昭和 52 年 2 月 9 日一部改定 \\ (論文・資料，研究速報，これすぽんでんす欄）}

1. 投稿者は原則として本会会員にかぎる。

2. 本会所定の原稿用紙に,「テレビジョン学会誌執 筆のしおり」に従って執筆し, 正 1 部, 副 2 部, 計 3 部提出する.ただし, 副はコピーです差支えない. 原稿用紙扔よび執筆のしおりは申込みにより送付す る。

3. 投稿欄は論文・資料，研究速報，これす涩んでん すの各欄とする．論文・資料欄の長さは原則として 刷上り 6 ページ以内 (表題, 図・表, 文献等字含む), 研究速報, これす渶んでんす欄は 2 ページ以内とす る. 1 ページは 375 字詰本会原稿用紙で約 6 枚.

投稿の際はページ数厳守のとと, ページ数が超過 している場合は，原則として返㞍する。

なお，各欄の内容はつぎのと打りとする。

論文・資料：テレビジョン技術および画像エレクト ロニクスに関係のある独創的な研究結 果の報告, あるいは会員の参考となる ような新しいデータ，設計資料，施設 計画資料, 試験報告等をまとめたもの.

研究速報：新しい着想や研究成果を速報するすの.

これすぼんでんす：読者の自由投稿のページであ

り, 既発表論文への討諭や学会 に対する建設的意見などを発表 するもの.

4. 投稿の内容はなるべく本会員多数のために理解し
やすく，かつ未公表*のものにかぎる。他の著作権 を侵した場合は投稿者の責任とする。

5. 投稿原稿は本会編集委員会で查読し，不適当と認 めたものは揭載しない。乙の場合，原稿は投稿者に 返㞍する。また，編集委員会が原稿の一部訂正を適 当と認めたときは，そのむ称搞者に照会する。

なお，投稿者に照会後，6力月以上経過して再送 稿されたものは新投稿原稿とみなす.

6. 図面のトレースは本会で行う.

7. 原稿が揭載された場合は，原则として別刷50部の 購入が義務づけられる。50部以上の別刷它希望する 場合は，筆者校正の際，希望部数を申出ること．

8. 原稿用紙，執篚のしおりの申込み，原稿の送付先 干 105 東京都港区芝公園 3-5-8 機械振興会館内 社団法人 テレビジョン学会

*論文・資料の原稿は，それが既発表または公知のもので ある場合は，投稿者に返戻するとととなりますが，当会 編集委員会における既発表のあのとは, 国内, 国外の学 会誌, 機関誌, 商業誌などに, その主要な部分が掲载さ れたむのを意味します。

ただし，次のものは未発表として取报います。（1)既発 表ではあるが，その一部を深く解析または実験し，その 部分にオリジナリティあるいは主張すべき点が認められ るむの, (2)研究速報欗に揭載されたものを一層充実させ て論文・資料として投稿したもの.

また, 研究会, 大会などの学術講演, 国際会議などに おける口頭発表諭文を諭文・資料として投稿されること は差支えありません。 


\title{
Sensitivity Differences between Central and Periferal Regions of Retina Measured by Critical Flicker Frequency
}

\author{
by Tadahiko Fukuda
}

CFF (Critical Flicker Frequency) determinations were made at various retinal positions by using a fixation point to which the line of vision is fixed in the first test and by employing a moving target which led the line of vision in the second test.

It is inferred from the results of the tests that CFF in the periphery is higher than that in the fovea when the target size is larger than $2^{\circ}$, and that the variation of CFF according to the locality on the retina in the case where the target size is very small (less than $1 / 8^{\circ}$ ) depends basically upon the density distribution of cones and rods on the retina.

It is also pointed out that CFF is higher during eye movement than when the line of vision is fixed, especially when the target size is large and in the periphery of the retina.

\section{Analysis of Correlation between Beam Discharge Lag and Scanning Electron Beam Performance in Pickup Tubes}

\section{by Mitsuhiro Kurashige}

In order to find out clues for improving the beam discharge lag in widely used photoconductive pickup tubes with blocking contacts, the author looked into the following aspects in the scanning electron beam performance as the factors affecting the lag: (1) Energy distribution broadening due to relaxation in the scanning beam. (2) Beam convergence angle on the target. (3) Angle of incidence of the beam on the target. (4) Local distribution of contact potential difference between target and cathode. (5) Second exponential region of the beam acceptance curves.

The author has worked out a computational procedure to follow the surface potential variation on the target and investigated the correlations among the beam performance, the resultant beam acceptance curves and the beam discharge lag.

It is concluded that the relaxation has the most predominant effect and that the other factors add only minor influence on the decay lag characteristics due to beam discharge.

\section{Analysis of Distortion Caused by Multipath Transmission in Frequency-modulation Sound Broadcasting}

\section{by Mitsuo Ohara}

Relations between distortion caused by multipath transmission and the essential parameters are analyzed for both monophonic and stereophonic FM sound broadcasting.

The parameters involved are DU ratio, delay time of the reflected wave in comparison with the direct wave, phase difference of these two carrier waves, modulation frequency and percentage of modulation.

Fast Fourier Transform processing technique is applied in the computer programme using which the complicated spectrum computation is carried out easily to allow a thorough analysis of multipath transmission phenomenon.

As a result, the complex nature of multipath distortion became clearly understandable. In addition, some considerations necessary for the better reception of FM sound broadcasting under the environment of multipath transmission are derived from the results of analysis. 